\title{
Urinary Melatonin-sulfate/cortisol Ratio and the Risk of Prostate Cancer: A Case-control Study
}

\author{
Emir Sahbal ${ }^{1}$, Hakan Celikhisar ${ }^{2}$, and Gulay Dasdemir Ilkhan ${ }^{3}$ \\ ${ }^{1}$ Cigli Regional Training Hospital \\ ${ }^{2}$ Affiliation not available \\ ${ }^{3}$ Okmeydani Training and Research Hospital
}

January 26, 2021

\begin{abstract}
Objective: The aim of the present study is to study the correlation between urinary cortisol and melatonin metabolites and prostate cancer. Method: Patients with a histologically confirmed new prostate carcinoma with no previous malignancies have been included in the study as "cases." Healthy individuals who applied to check-up and sleep disorder polyclinics were included as the healthy control group. Serum prostate-specific antigen (PSA), urinary melatonin sulfate, and cortisol levels in the firstmorning spot urine samples were measured during the admission and diagnosis for all participants. Results: A total of 180 patients with a proven pathology of prostate adenocarcinoma and 240 healthy males participated in the study as the control group. When compared with the control group, significantly lower urinary melatonin sulfate levels $(49.85 \pm 46.58) \mathrm{ng} / \mathrm{mg} \mathrm{vs}$. $(64.25 \pm 66.75) \mathrm{ng} / \mathrm{mg}, \mathrm{p}=0.003)$ and significantly lower melatonin sulfate/cortisol $(\mathrm{M} / \mathrm{C})$ ratios $(2.38 \pm 3.20 \mathrm{vs.} 5.28 \pm 15.32$ $\mathrm{p}<0.001$ ) (respectively) levels were found in the patients. Subjects who had high M/C ratios and urinary melatonin-sulfate were less exposed to risk of prostate cancer at a statistically significant rate than those with lower urinary melatonin-sulfate or $\mathrm{M} / \mathrm{C}$ ratios. We also discovered that subjects with a low $\mathrm{M} / \mathrm{C}$ ratio and preoperative PSA levels above $10 \mathrm{ng} / \mathrm{mL}$ were 3.58 times more likely $(95 \% \mathrm{CI}=1.58-8.12)$ to develop prostate cancer than those with a high $\mathrm{M} / \mathrm{C}$ ratio and preoperative low PSA $(<10 \mathrm{ng} / \mathrm{mL})$. Conclusion: We concluded that there was association between lower morning melatonin sulfate levels or M/C ratio and the risk of prostate cancer. Moreover, patients who had both low PSA levels and M/C ratios higher than $10 \mathrm{ng} / \mathrm{mL}$ were much more exposed to advanced (end-stage) disease and prostate cancer.
\end{abstract}

\section{Introduction}

Urological cancers constituting $12 \%$ of deaths related to malignancy worldwide are mostly comprised of prostate, bladder, and kidney cancers. The most common type of cancer is the prostate cancer with 300,000 deaths and one million new cases each year ${ }^{1,2}$. Melatonin is a neuroendocrine hormone that has antioxidant and anticarcinogenic properties and is primarily synthesized by the pineal gland. Apart from the pineal gland, melatonin synthesis is also accomplished through many organs such as the gastrointestinal system, bone marrow, retina, the skin, and lymphocytes ${ }^{3}$. Melatonin presents exceptional systemic function diversity and has important functions including anti-inflammatory properties, antioxidant and immunomodulation effects, and effects on energy metabolism and hematopoiesis as well as pro-apoptotic, antinociceptive, and antiproliferation activities ${ }^{4}$. Additionally, cortisol is the resulting product of the hypothalamus-pituitaryadrenal axis, is secreted in a pulsatile manner showing circadian rhythm, and is an important hormone for circadian regulation ${ }^{5,6,7}$. In a study, it was discovered that the patterns of cortisol secretion may be affected by shift working causing circadian disruption ${ }^{8}$. It has been discovered that this hormone triggers the risk of cancer through its effects on immune function ${ }^{9,10}$. For this reason, it is highly likely that the carcinogenicity of circadian disruption affects many areas for both women and men through cortisol levels and melatonin. Long and short -term side effects and risk of cancer may be due to disharmony between the sleep/wake cycle and 
the endogenous circadian timing system and the disruption of circadian rhythms ${ }^{11}$. A hormone, Melatonin, which is secreted by the human pineal gland, has significant anticancer potential in various in vitro and in vivo experimental neoplasia models with chemopreventive, oncostatic, and tumor inhibitory effects ${ }^{4-6}$. Melatonin is also an effective and powerful endogenous hydroxyl radical scavenger and immunomodulatory agent with the direct and indirect anticancer effects ${ }^{11}$. Most studies on melatonin in the past thirty years have focused on breast cancer, which is the most common type of cancer observed in women ${ }^{12,13}$, but there have been few studies conducted on the potential effect of melatonin on prostate cancer ${ }^{14,15}$. The similarity of the breast and prostate cancer is due to their dependency on sex hormones ${ }^{16,17}$. In several studies, a correlation was revealed between breast cancer and circadian disruption. However, few studies have examined the correlation between sleep loss or circadian disruption and prostate cancer risk. For this reason, this study evaluated the correlation between melatonin and cortisol levels as the two urinary biomarkers, and examined the effects of circadian regulation hormones on the presence and the stage of prostate cancer and prostate cancer. PSA serum concentration is a marker used in the presence of prostate cancer with the follow-up of patients in order to detect relapse in patients ${ }^{18}$. We included PSA in the study parameters to study the interaction and correlation between circadian regulation hormones in prostate cancer patients.

\section{Methods}

\section{Study Design}

The present cross-sectional study was conducted as the case-control study at hospital between January 2016 and April 2020 in three centers, the University of Health Sciences Okmeydani Training and Research Hospital, Izmir Metropolitan Municipality Hospital, and Tire State Hospital. The study was approved by the local ethics committee (Bezmialem University Non-interventional Research Ethics Committee Number 2011- KAEK-25 2015/24-11), and all participants of the study filled in the informed consent form.

\section{Participants}

180 male patients with a histologically proven diagnosis of prostate adenocarcinoma were included in the study, and those with a previous diagnosis of cancer in another body part were excluded. Individuals with either the usual digital rectal examination or remarkable digital rectal examination findings but benign prostatic hyperplasia $(\mathrm{BPH})$ which is histologically confirmed without malignancy were included in the control group. The control group consisted of 240 male individuals whose ages were the same as the patients.

\section{Study Protocol}

Clinical and demographic characteristics of the participants in both groups such as education, age, family history of prostate cancer, marital status, surgeries, systemic diseases, smoking, alcohol use, and vitamin D use were recorded by face-to-face interviews. Serum prostate-specific antigen (PSA) levels of all cases in diagnosis and disease stages were recorded by reviewing their medical records because the diagnosis date of the cases, the time of cytological evidence, was accepted as the reference. Controls were matched in the reference month in the same month. The measured PSA results were collected by reviewing medical records of the controls.

\section{Sample Collection and Assessment}

First spot urine samples were taken in the morning from the case and control groups. Each of the samples was divided into $4.5 \mathrm{~mL}$ tubes and then kept in storage at $-20^{\circ} \mathrm{C}$. Urine samples from the patients and the matched control group were processed in the same way and tested at the same time for the same study. All of the samples were simultaneously taken from the freezer and transferred to the laboratory on dry ice. The laboratory staff was blinded to the all samples' case control status. Two standard samples were included in each test to check the analytical error. Morning urine measurements revealed good sensitivity and specificity in determining individual differences in nocturnal plasma melatonin levels ${ }^{19}$.

A solid-phase type of enzyme immunoassay was used to measure urinary melatonin sulfate was measured (Melatonin Sulphate ELISA Kit, GenWay Biotech Inc. San Diego, USA). Test sensitivity was 1.0 ng/dL. 
Intra- and inter-assay coefficients of variation had the upper limits ranged between 5.0-12.5\% and 5.1- 15.1\%, respectively, at $5.7-205 \mathrm{ng} / \mathrm{dL}$ and 12.5-230 ng/dL. automatic photometer (ELx808 Absorbance Microplate Reader) was used to measure optical density at $450 \mathrm{~nm}$.

A chemiluminescent immunoassay was used to measure urine cortisol performed on an ADVIA Centaur XP Immunoassay System analyzer (Siemens Healthcare Diagnostics Ltd. Frimley, Camberley, UK). Test sensitivity was obtained as $0.1 \mu \mathrm{g} / \mathrm{dL}$. The upper limits of inter-assay and intra-assay coefficients of variation were $1.85-5.50 \%$ and, $2.91-3.79 \%$ respectively, at 3.90-36.95 $\mathrm{ng} / \mathrm{dL}$. The modified Jaffe reaction method was used to measure the urine creatinine levels. Urinary creatinine levels corrected the urine melatonin-sulfate and cortisol levels ${ }^{19}$.

\section{Statistical Analysis}

The combined effect of melatonin and cortisol levels on prostate cancer could be measured at the same time to calculate the urinary melatonin-sulfate/cortisol (M/C) ratio by dividing urinary melatonin-sulfate levels by urinary cortisol levels. Differences between the patient and control groups in urinary biomarkers such as cortisol, melatonin-sulfate, and the M/C ratio were studied using the Wilcoxon Rank-Sum Test. Furthermore, we dichotomized these urinary markers with medians of $23.92 \mathrm{ng} / \mathrm{mg}$ creatinine for cortisol, 1.81 for the $\mathrm{M} / \mathrm{C}$ ratio, and $42.83 \mathrm{ng} / \mathrm{mg}$ creatinine for melatonin. $95 \%$ confidence intervals (CIs) and odds ratios (OR) were estimated using the unconditional logistic regression models for the correlation between urinary markers and risk of prostate cancer. Family history of prostate cancer, habits (smoking, alcohol), age at the time of the study ( $<65$ vs. [?] 65 years), PSA level ( $<10 \mathrm{vs.}>10 \mathrm{ng} / \mathrm{mL}$ ) were considered for all analyses.

The cases were also categorized as advanced (end-stage) cancer (extraprostatic stage T3a or higher, N1/M1) and localized prostate cancer (stage $\mathrm{T} 2$ or T1) ${ }^{20}$. The risks of developing advanced (end-stage) and localized prostate cancer based on the control group were determined using the multi-category logistic regression models. Polytomous logistic models containing categorical variables and their cross-products were fitted to appraise multiplicative interaction. The significance of multiplicative interaction was evaluated for each pair of comparison using the Wald Z-tests for cross-product terms. All two-sided p-values were considered significant if $<0.05$.

\section{Results}

In total, we identified 197 patients with a proven pathology of prostate adenocarcinoma and 274 male controls between January 2016 and April 2020. After excluding other cancer cases or cases without individual matches, 180 patients and 240 controls were included in our study. Table 1 related to the summary of participant characteristics shows the only significant difference between controls and cases was the PSA levels $(\mathrm{p}<0.001)$. Most of the study participants were 65 years above $(75.2 \%)$, married $(87.7 \%)$, most of them had college or high school degrees $(76.7 \%)$, were nonsmokers $(70.1 \%)$, took no vitamin D supplements $(96.6 \%)$ and had no history of prostate cancer in the family (85.5\%). Only a minority used alcohol (11.2\%). The two groups had no statistically significant difference in terms of these characteristics (p: 0.64). When compared to the control group, significantly lower urinary melatonin sulfate levels $(49.85 \pm 46.58$ vs. 64.25 $\pm 66.75 \mathrm{ng} / \mathrm{mg}$ creatinine, $\mathrm{p}=0.003)$ and lower $\mathrm{M} / \mathrm{C}$ ratios $(2.38 \pm 3.20$ vs. $5.28 \pm 15.32, \mathrm{p}<0.001$, respectively) were detected in the patients. However, there were significantly higher mean levels of urinary cortisol in the cases had than those in the controls $(33.12 \pm 29.42$ vs. $26.65 \pm 20.85 \mathrm{ng} / \mathrm{mg}$ creatinine, $\mathrm{p}=$ 0.007 , respectively).

After other common variables were adjusted, we discovered that subjects who had a high $\mathrm{M} / \mathrm{C}$ ratios or urinary melatonin-sulfate level were significantly less exposed to prostate cancer than those who had a low $\mathrm{M} / \mathrm{C}$ ratios and urinary melatonin-sulfate level $(\mathrm{aOR}=0.45$, and $95 \% \mathrm{CI}=0.31-0.81$; and adjusted OR $[\mathrm{aOR}]=0.61$, and $95 \% \mathrm{CI}=0.34-0.98$, respectively) (Table 2 ). In addition, we discovered that subjects with both a low $\mathrm{M} / \mathrm{C}$ ratio and preoperative PSA levels above $10 \mathrm{ng} / \mathrm{mL}$ were 3.58 times more likely $(95 \%$ $\mathrm{CI}=1.58-8.12)$ to develop prostate cancer compared to those with a high $\mathrm{M} / \mathrm{C}$ ratio and preoperative low PSA $(<10 \mathrm{ng} / \mathrm{mL})$ (Table 2). The group with low preoperative PSA levels and M/C ratios exceeding 10 
$\mathrm{ng} / \mathrm{mL}(\mathrm{aOR}=8.79 ; 95 \% \mathrm{CI}=4.01-18.97)$ was exposed to higher risks. When the risk of melatonin sulfate or cortisol and PSA level was combined, the subjects l showed a similar risk pattern. While prostate cancer was categorized according to the clinical stage i.e. advanced and localized, we discovered some statistically significant differences in urine biomarkers during the comparison of the advanced (end-stage) cancer group and the control group. The M/C ratio and PSA level A did not yield multiplicative scale of interaction (Table 3). Furthermore, we found that the advanced (end-stage) cancer group had combined effect of a lower preoperative PSA levels and M/C ratio exceeding $10 \mathrm{ng} / \mathrm{mL}$ than the localized cancer group or control group (Table 3). When evaluating melatonin sulfate, cortisol, and PSA levels in combination, the subjects had a similar trend pattern.

\section{Discussion}

The focus of most previous studies was on evaluation of the correlation between breast cancer and melatonin levels while there is quite limited number of studies examining the correlation between melatonin and prostate cancer. A cross-sectional study carried out by Bartsch et al. revealed that there were lower melatonin levels among the men who had prostate cancer than that in men with $\mathrm{BPH}^{21}$. In a case-cohort study in the Icelandic population, it was found that subjects whose first morning urinary 6-sulfatoxymelatonin (aMT6s) levels were below the median level were exposed to a 4-fold higher risk than the subjects with aMT6s levels above the median level (hazard ratio $=4.04 ; 95 \% \mathrm{CI}=1.26-12.98)^{22}$. On the contrary, in the present study, no significant correlation was found between morning urinary aMT6 levels and total risk of prostate cancer. In fact, in our study, there was a statistically significant negative correlation between the melatonin/cortisol $(\mathrm{M} / \mathrm{C})$ ratio and first-morning urinary melatonin-sulfate levels and the risk of advanced (end-stage) prostate cancer and general prostate cancer. In our study, we strongly believe that our results will contribute to the literature on prostate cancer risk and the circadian hormones. Melatonin had the protective effect on risk of cancer due to inhibiting growth of cancer cell, which protects cells against damage of DNA, and promotes DNA repair after it occurs ${ }^{1,23,24}$. Blask et al. recently used both steroid receptor-negative and receptor-positive human breast cancer xenografts in rats to perform a series of experiments and to discover an inverse correlation between tumor activity and melatonin level ${ }^{25}$. Similar results with prostate cancer xenografts were reported in similar research group ${ }^{26}$. In other studies, a decrease in the malignant prostate tumor cells growth has been reported with the administration of both pharmacological and physiological doses of melatonin ${ }^{27}$.

In our study, we further measured another important circadian hormone i.e. cortisol, secreted by the adrenal cortex. Cortisol has been found to regulate both inflammation and immunity. This hormone deficiency can disrupt the immune system, and immune reactions may be suppressed by excessive hormone ${ }^{28}$. Furthermore, there has been association between the chronic irregularity of rhythm of the circadian cortisol and increasing inflammation which is highly effective in carcinogenesis ${ }^{28,29}$. Mirick et al. found the effect of circadian disruption on the pattern of cortisol secretion release, increasing the risk of cancer ${ }^{30}$. Even though the present study found no significant correlation between prostate cancer and spot morning urinary cortisol level, we found an inverse correlation between advanced (end-stage) prostate cancer and prostate cancer and the M/C ratio. In the previous studies, the $\mathrm{M} / \mathrm{C}$ ratio was related to the depression severity and different types of depression $^{31,32}$. However, as far as we know, our study is one of the few studies evaluating the correlation between prostate cancer and the $\mathrm{M} / \mathrm{C}$ ratio.

Whether to undergo an invasive prostate biopsy for subjects with abnormal PSA levels can be clinically determined with difficulty. The results of our study which support the conclusion that combined low M/C ratios and PSA levels exceeding $10 \mathrm{ng} / \mathrm{mL}$ indicates that a person is exposed to advanced (end-stage) prostate cancer and prostate cancer, suggesting that the M/C ratio should be considered a biomarker. The urine M/C ratio will be additionally used to decide if a prostate biopsy is necessary with increasing PSA levels. More studies are needed in order to examine the clinical utility of evaluation by combining PSA and M/C ratio for detecting the prostate cancer and the disease stage.

In our study, the male control group also had a high PSA level exceeding $10 \mathrm{ng} / \mathrm{mL}$. The serum of patients with prostate cancer and $\mathrm{BPH}$ was expected to have higher concentrations of PSA ${ }^{33}$. An estimated $50 \%$ of 
50-year-old men, $75 \%$ of 80 -year-olds, and $90 \%$ of 85 -year-old men have histological evidence of $\mathrm{BPH}^{34}$. Men aged above 50 had about $99 \%$ of prostate cancer ${ }^{35}$. This is particularly problematic in older men with more prevalent $\mathrm{BPH}$ due to increase of glandular volume with BPH so that the PSA level and the sampling errors number related to prostate biopsy is enhanced ${ }^{34}$. While prostate cancer detection rates in Caucasian men can be as high as $40 \%$ for men whose PSA is $4-10 \mathrm{ng} / \mathrm{mL}$, prostate cancer is observed in only $20 \%$ of Chinese men with the same level of $\mathrm{PSA}^{36}$. In our control group, the inclusion criteria include either remarkable or unremarkable digital rectal exams but with BPH confirmed histologically. For this reason, some male patients with undiagnosed prostate cancer may have been included in our control group. However, the inclusion of such patients in the control group would only lead to an underestimation of the correlation that is happening.

One of the strengths of our study is that we evaluated the most important risk factors of prostate cancer in our analyses, including PSA level and clinical stage. Furthermore, two important circadian biomarkers were evaluated and then the $\mathrm{M} / \mathrm{C}$ ratio was discovered to be more relevant for prostate cancer. There are some limitations in the present study. The first limitation is its cross-sectional and case-control nature. For this reason, a precise causal relationship cannot be inferred. If sleep interruption or circadian disruption after diagnosis of a cancer causes melatonin levels to drop, there is a possibility of inverse causation between prostate cancer and circadian hormones. A further limitation is our use of one spot morning urine biomarkers single measurement not representing long-term exposure levels. Even though we have extensive knowledge of various covariates and can easily control possible confounders, we still did not know about factors such as the presence of sleep disorders or drug use. As a consequence, the related exposures and risks were gathered with a questionnaire, leading to some recall bias.

\section{Conclusion}

An association was found between the reducing $\mathrm{M} / \mathrm{C}$ ratio or morning urinary melatonin-sulfate levels and the risk of prostate cancer. We also found that patients whose $\mathrm{M} / \mathrm{C}$ ratios and PSA levels beyond $10 \mathrm{ng} / \mathrm{mL}$ were low had much higher risk of advanced (end-stage) disease and prostate cancer. Due to this cross-sectional and case-control nature of the study, it was not possible to establish an accurate causal relationship between prostate cancer risk and the urinary $\mathrm{M} / \mathrm{C}$ ratio. These results can be confirmed with some larger prospective cohort studies.

\section{What's known}

There are many studies that evaluate the correlation between levels of melatonin and breast cancer. However, there are not enough studies in the literature that examine prostate cancer and melatonin. Cortisol is well known to control both inflammation and immunity. There is also an association between the chronic irregularity of the circadian cortisol rhythm and high levels of inflammation and a weakened immune system.

\section{What's new}

We found a statistically significant correlation between lower M/C ratio or levels of first spot urinary melatonin-sulfate and the risk of prostate cancer. Furthermore, we reached the conclusion that patients with both low PSA levels and $\mathrm{M} / \mathrm{C}$ ratios beyond $10 \mathrm{ng} / \mathrm{mL}$ were much more exposed to advanced (end-stage) disease and prostate cancer.

Conflict of Interest: There is no conflict of interest in the present study.

Financial Disclosure: No financial support or funds were used for the study.

Acknowledgements: none declared

\section{References}

1. Center MM, Jemal A, Lortet-Tieulent J, Ward E, Ferlay J, Brawley O, Bray F. International variation in prostate cancer incidence and mortality rates. Eur Urol. 2012;61(6):1079-92.

2. Cipolla-Neto J, Amaral FGD. Melatonin as a Hormone: New Physiological and Clinical Insights. Endocr Rev. 2018 Dec 1;39(6):990-1028. doi: 10.1210/er.2018-00084. PMID: 30215696. 
3. M.Singh, H.R. Jadhav. Melatonin: functions and ligands. Drug Discov. Today. 2014;19(9):1410-1418.

4. Claustrat B, Leston J. Melatonin: Physiological effects in humans. Neurochirurgie. 2015 Apr-Jun;61(23):77-84. doi: 10.1016/j.neuchi.2015.03.002. Epub 2015 Apr 20. PMID: 25908646.

5. de Weerth C, Zijl RH, Buitelaar JK. Development of cortisol circadian rhythm in infancy. Early Hum Dev. 2003 Aug;73(1-2):39-52. doi: 10.1016/s0378-3782(03)00074-4. PMID: 12932892.

6. Law R, Hucklebridge F, Thorn L, Evans P, Clow A. State variation in the cortisol awakening response. Stress. 2013 Sep;16(5):483-92. doi: 10.3109/10253890.2013.817552. Epub 2013 Jul 29. PMID: 23805796.

7. Pierre K, Rao RT, Hartmanshenn C, Androulakis IP. Modeling the Influence of Seasonal Differences in the HPA Axis on Synchronization of the Circadian Clock and Cell Cycle. Endocrinology. 2018 Apr 1;159(4):1808-1826. doi: 10.1210/en.2017-03226. PMID: 29444258; PMCID: PMC6044315.

8. Gómez-Acebo I, Dierssen-Sotos T, Papantoniou K, García-Unzueta MT, Santos-Benito MF, Llorca J. Association between exposure to rotating night shift versus day shift using levels of 6sulfatoxymelatonin and cortisol and other sex hormones in women. Chronobiol Int. 2015 Feb;32(1):12835. doi: 10.3109/07420528.2014.958494. Epub 2014 Sep 12. PMID: 25216206.

9. DeSantis AS, DiezRoux AV, Hajat A, Aiello AE, Golden SH, Jenny NS, Seeman TE, Shea S. Associations of salivary cortisol levels with inflammatory markers: the Multi-Ethnic Study of Atherosclerosis. Psychoneuroendocrinology. 2012 Jul;37(7):1009-18. doi: 10.1016/j.psyneuen.2011.11.009. Epub 2011 Dec 16. PMID: 22178583; PMCID: PMC3358540.

10. Li Y, Li S, Zhou Y, Meng X, Zhang JJ, Xu DP, Li HB. Melatonin for the prevention and treatment of cancer. Oncotarget. 2017 Jun 13;8(24):39896-39921. doi: 10.18632/oncotarget.16379. PMID: 28415828; PMCID: PMC5503661.

11. Talib WH. Melatonin and Cancer Hallmarks. Molecules. 2018 Feb 26;23(3):518. doi: 10.3390/molecules23030518. PMID: 29495398; PMCID: PMC6017729.

12. Kubatka P, Zubor P, Busselberg D, Kwon TK, Adamek M, Petrovic D, Opatrilova R, Gazdikova K, Caprnda M, Rodrigo L, Danko J, Kruzliak P. Melatonin and breast cancer: Evidences from preclinical and human studies. Crit Rev Oncol Hematol. 2018 Feb;122:133-143. doi: 10.1016/j.critrevonc.2017.12.018. Epub 2017 Dec 29. PMID: 29458781.

13. Veiga ECA, Simões R, Valenti VE, Cipolla-Neto J, Abreu LC, Barros EPM, Sorpreso ICE, Baracat MCP, Baracat EC, Soares Junior JM. Repercussions of melatonin on the risk of breast cancer: a systematic review and meta-analysis. Rev Assoc Med Bras (1992). 2019 Jun 3;65(5):699-705. doi: 10.1590/1806-9282.65.5.699. PMID: 31166448.

14. Mayo JC, Hevia D, Quiros-Gonzalez I, Rodriguez-Garcia A, Gonzalez-Menendez P, Cepas V, GonzalezPola I, Sainz RM. IGFBP3 and MAPK/ERK signaling mediates melatonin-induced antitumor activity in prostate cancer. J Pineal Res. 2017 Jan;62(1). doi: 10.1111/jpi.12373. Epub 2016 Nov 9. PMID: 27736013.

15. Calastretti A, Gatti G, Lucini V, Dugnani S, Canti G, Scaglione F, Bevilacqua A. Melatonin Analogue Antiproliferative and Cytotoxic Effects on Human Prostate Cancer Cells. Int J Mol Sci. 2018 May 18;19(5):1505. doi: 10.3390/ijms19051505. PMID: 29783631; PMCID: PMC5983593.

16. Calastretti A, Gatti G, Lucini V, Dugnani S, Canti G, Scaglione F, Bevilacqua A. Melatonin Analogue Antiproliferative and Cytotoxic Effects on Human Prostate Cancer Cells. Int J Mol Sci. 2018 May 18;19(5):1505. doi: 10.3390/ijms19051505. PMID: 29783631; PMCID: PMC5983593.

17. Calastretti A, Gatti G, Lucini V, Dugnani S, Canti G, Scaglione F, Bevilacqua A. Melatonin Analogue Antiproliferative and Cytotoxic Effects on Human Prostate Cancer Cells. Int J Mol Sci. 2018 May 18;19(5):1505. doi: 10.3390/ijms19051505. PMID: 29783631; PMCID: PMC5983593.

18. Rao AR, Motiwala HG, Karim OM. The discovery of prostate-specific antigen. BJU Int. 2008 Jan;101(1):5-10. doi: 10.1111/j.1464-410X.2007.07138.x. Epub 2007 Aug 30. PMID: 17760888.

19. Rzepka-Migut B, Paprocka J. Melatonin-Measurement Methods and the Factors Modifying the Results. A Systematic Review of the Literature. Int J Environ Res Public Health. 2020 Mar 15;17(6):1916. doi: 10.3390/ijerph17061916. PMID: 32183489; PMCID: PMC7142625.

20. Xiao WJ, Zhu Y, Zhu Y, Dai B, Ye DW. Evaluation of clinical staging of the American Joint Committee on Cancer (eighth edition) for prostate cancer. World J Urol. 2018 May;36(5):769-774. doi: 
10.1007/s00345-018-2183-0. Epub 2018 Jan 25. PMID: 29372356.

21. Bartsch C, Bartsch H, Schmidt A, Ilg S, Bichler KH, Flüchter SH. Melatonin and 6-sulfatoxymelatonin circadian rhythms in serum and urine of primary prostate cancer patients: evidence for reduced pineal activity and relevance of urinary determinations. Clin Chim Acta. 1992 Aug 31;209(3):153-67. doi: 10.1016/0009-8981(92)90164-l. PMID: 1395046.

22. Sigurdardottir LG, Markt SC, Rider JR, Haneuse S, Fall K, Schernhammer ES, Tamimi RM, FlynnEvans E, Batista JL, Launer L, Harris T, Aspelund T, Stampfer MJ, Gudnason V, Czeisler CA, Lockley SW, Valdimarsdottir UA, Mucci LA. Urinary melatonin levels, sleep disruption, and risk of prostate cancer in elderly men. Eur Urol. 2015 Feb;67(2):191-4. doi: 10.1016/j.eururo.2014.07.008. Epub 2014 Aug 5. PMID: 25107635; PMCID: PMC4318783.

23. Blask DE, Sauer LA, Dauchy RT. Melatonin as a chronobiotic/anticancer agent: cellular, biochemical, and molecular mechanisms of action and their implications for circadian-based cancer therapy. Curr Top Med Chem. 2002 Feb;2(2):113-32. doi: 10.2174/1568026023394407. PMID: 11899096.

24. Reiter RJ, Tan DX, Erren TC, Fuentes-Broto L, Paredes SD. Light-mediated perturbations of circadian timing and cancer risk: a mechanistic analysis. Integr Cancer Ther. 2009 Dec;8(4):354-60. doi: 10.1177/1534735409352026. PMID: 20042411.

25. Pariollaud M, Lamia KA. Cancer in the Fourth Dimension: What Is the Impact of Circadian Disruption? Cancer Discov. 2020 Oct;10(10):1455-1464. doi: 10.1158/2159-8290.CD-20-0413. Epub 2020 Sep 15. PMID: 32934020; PMCID: PMC7541588.

26. Blask DE, Brainard GC, Dauchy RT, Hanifin JP, Davidson LK, Krause JA, Sauer LA, Rivera-Bermudez MA, Dubocovich ML, Jasser SA, Lynch DT, Rollag MD, Zalatan F. Melatonin-depleted blood from premenopausal women exposed to light at night stimulates growth of human breast cancer xenografts in nude rats. Cancer Res. 2005 Dec 1;65(23):11174-84. doi: 10.1158/0008-5472.CAN-05-1945. PMID: 16322268.

27. Blask DE, Dauchy RT, Brainard GC, Hanifin JP. Circadian stage-dependent inhibition of human breast cancer metabolism and growth by the nocturnal melatonin signal: consequences of its disruption by light at night in rats and women. Integr Cancer Ther. 2009 Dec;8(4):347-53. doi: 10.1177/1534735409352320. PMID: 20042410.

28. Jung-Hynes B, Huang W, Reiter RJ, Ahmad N. Melatonin resynchronizes dysregulated circadian rhythm circuitry in human prostate cancer cells. J Pineal Res. 2010 Aug;49(1):60-8. doi: 10.1111/j.1600079X.2010.00767.x. Epub 2010 May 27. PMID: 20524973; PMCID: PMC3158680.

29. Jung-Hynes B, Schmit TL, Reagan-Shaw SR, Siddiqui IA, Mukhtar H, Ahmad N. Melatonin, a novel Sirt1 inhibitor, imparts antiproliferative effects against prostate cancer in vitro in culture and in vivo in TRAMP model. J Pineal Res. 2011 Mar;50(2):140-9. doi: 10.1111/j.1600-079X.2010.00823.x. Epub 2010 Nov 9. PMID: 21062352; PMCID: PMC3052633.

30. Cole TJ, Short KL, Hooper SB. The science of steroids. Semin Fetal Neonatal Med. 2019 Jun;24(3):170175. doi: 10.1016/j.siny.2019.05.005. Epub 2019 May 23. PMID: 31147162.

31. Singh N, Baby D, Rajguru JP, Patil PB, Thakkannavar SS, Pujari VB. Inflammation and cancer. Ann Afr Med. 2019 Jul-Sep;18(3):121-126. doi: 10.4103/aam.aam_56_18. PMID: 31417011; PMCID: PMC6704802.

32. Mirick DK, Bhatti P, Chen C, Nordt F, Stanczyk FZ, Davis S. Night shift work and levels of 6sulfatoxymelatonin and cortisol in men. Cancer Epidemiol Biomarkers Prev. 2013 Jun;22(6):1079-87. doi: 10.1158/1055-9965.EPI-12-1377. Epub 2013 Apr 5. PMID: 23563887; PMCID: PMC4772962.

33. Wetterbuerg L, Beck-Friis J, Aperia B, Petterson U. Melatonin/cortisol ratio in depression. Lancet. 1979 Dec 22-29;2(8156-8157):1361. doi: 10.1016/s0140-6736(79)92837-x. PMID: 92692.

34. Vezyraki P, Vlachaki A, Baltogiannis D, Batistatou A, Tsampalas S, V Simos Y, Kaltsas A, Pappas P, Dounousi E, Ragos V, Tsiambas E, Peschos D. Impact of total PSA and percent free PSA in the differentiation of prostate disease: a retrospective comparative study implicating neoplastic and non-neoplastic entities. J BUON. 2019 Sep-Oct;24(5):2107-2113. PMID: 31786882.

35. Fu S, Zhang X, Niu Y, Wang RT. Prostate Specific Antigen, Mean Platelet Volume, and Platelet Distribution Width in Combination to Discriminate Prostate Cancer from Benign Prostate Hyperpla- 
sia. Asian Pac J Cancer Prev. 2018 Mar 27;19(3):699-702. doi: 10.22034/APJCP.2018.19.3.699. PMID: 29580043; PMCID: PMC5980844.

36. Costa P, Ben Naoum K, Boukaram M, Wagner L, Louis JF. Hyperplasie bénigne de la prostate (HBP) : prévalence en médecine générale et attitude pratique des médecins généralistes français. Résultats d'une etude réalisée auprès de 17.953 patients [Benign prostatic hyperplasia $(\mathrm{BPH})$ : prevalence in general practice and practical approach of French general practitioners. Results of a study based on 17,953 patients]. Prog Urol. 2004 Feb;14(1):33-9. French. PMID: 15098749.

Table 1. Demographic characteristics of all participants.

\begin{tabular}{|c|c|c|c|}
\hline & Patients $(n=180)$ & Controls $(n=240)$ & $\chi^{2} \tau \varepsilon \sigma \tau \pi \alpha \lambda \cup \varepsilon$ \\
\hline & n (\%) & n (\%) & \\
\hline Age [?]65 years ¡65 years & $136(75.6) 44(24.4)$ & $180(75.0) 60(25.0)$ & 0.803 \\
\hline $\begin{array}{l}\text { Education [?] university } \\
\text { high school \& college }\end{array}$ & $43(23.9) 137(76.1)$ & $52(21.9) 185(78.1)$ & 0.642 \\
\hline $\begin{array}{l}\text { Marital status married } \\
\text { others }\end{array}$ & $163(90.5) 17(9.5)$ & $205(86.1) 33(13.9)$ & 0.198 \\
\hline $\begin{array}{l}\text { Family history of } \mathrm{PCa}^{*} \\
\text { Yes No }\end{array}$ & $30(16.6) 150(83.4)$ & $31(13.3) 203$ (86.7) & 0.348 \\
\hline $\begin{array}{l}\text { Smoking Former or } \\
\text { current Never }\end{array}$ & $54(30.0) 126(70.0)$ & $81(29.8) 167(70.2)$ & 0.982 \\
\hline $\begin{array}{l}\text { Alcohol Former or } \\
\text { current Never }\end{array}$ & $27(15.0) 153(85.0)$ & $22(9.2) 216(90.8)$ & 0.098 \\
\hline $\begin{array}{l}\text { Vitamin D supplement } \\
\text { Yes No }\end{array}$ & $2(1.1) 178(98.9)$ & $11(4.6) 227(95.4)$ & $0.072^{* * *}$ \\
\hline $\begin{array}{l}\text { Preoperative PSA** level } \\
{[?] 10 \mathrm{ng} / \mathrm{mL} ; 10 \mathrm{ng} / \mathrm{mL}}\end{array}$ & $139(77.2) 41(22.7)$ & $109(47.6) 120(52.4)$ & ¡0.001 \\
\hline
\end{tabular}

*Prostate cancer; ** Prostate-specific antigen;*** Fisher's exact test.

Table 2. Association between urinary biomarkers of circadian hormone dichotomized by medians and the presence of prostate cancer

\begin{tabular}{|c|c|c|c|c|c|c|c|}
\hline Variables & Variables & $\begin{array}{l}\text { Controls } \\
n=240\end{array}$ & $\begin{array}{l}\text { Patients } \\
n=180\end{array}$ & OR & $95 \% \mathrm{CI}$ & $\mathrm{aOR}^{\mathrm{a}}$ & $95 \% \mathrm{CI}$ \\
\hline & & n (\%) & n (\%) & & & & \\
\hline Melatonin ${ }^{b}$ & Melatonin ${ }^{b}$ & Melatonin ${ }^{b}$ & Melatonin b & Melatonin $^{\mathrm{b}}$ & Melatonin ${ }^{b}$ & Melatonin ${ }^{b}$ & Melatonin $^{\mathrm{b}}$ \\
\hline Low & & $108(45.0)$ & $109(60.5)$ & 1.0 & (ref) & 1.0 & (ref) \\
\hline High & & $132(55.0)$ & $71(39.4)$ & 0.52 & $0.29-0.79$ & 0.61 & $0.34-0.98$ \\
\hline Cortisol $^{b}$ & Cortisol $^{\mathrm{b}}$ & Cortisol $^{\mathrm{b}}$ & Cortisol $^{\mathrm{b}}$ & Cortisol $^{\mathrm{b}}$ & Cortisol $^{\mathrm{b}}$ & Cortisol $^{\mathrm{b}}$ & Cortisol $^{\mathrm{b}}$ \\
\hline Low & & $129(53.7)$ & $75(41.7)$ & 1.0 & (ref) & 1.0 & (ref) \\
\hline High & & $111(46.3)$ & $105(58.3)$ & 1.74 & $1.11-2.61$ & 1.43 & $0.85-2.32$ \\
\hline $\mathrm{MT} / \mathrm{C}^{\mathrm{c}}$ & $\mathrm{MT} / \mathrm{C}^{\mathrm{c}}$ & $\mathrm{MT} / \mathrm{C}^{\mathrm{c}}$ & $\mathrm{MT} / \mathrm{C}^{\mathrm{c}}$ & $\mathrm{MT} / \mathrm{C}^{\mathrm{c}}$ & $\mathrm{MT} / \mathrm{C}^{\mathrm{c}}$ & $\mathrm{MT} / \mathrm{C}^{\mathrm{c}}$ & $\mathrm{MT} / \mathrm{C}^{\mathrm{c}}$ \\
\hline Low & & $106(44.2)$ & $112(62.2)$ & 1.0 & (ref) & $1.0^{\circ}$ & (ref) \\
\hline High & & $134(55.8)$ & $68(37.8)$ & 0.51 & $0.28-0.69$ & 0.51 & $0.31-0.81$ \\
\hline $\mathrm{MT} / \mathrm{C}$ & $\operatorname{PSA}^{\mathrm{d}}$ & & & & & & \\
\hline High & ¡10 & $63(26.3)$ & $15(8.3)$ & 1.0 & (ref) & 1.0 & (ref) \\
\hline Low & ¡10 & $57(23.7)$ & $24(13.3)$ & 1.79 & $0.81-4.41$ & 1.89 & $0.81-4.58$ \\
\hline High & {$[?] 10$} & $61(25.4)$ & $51(28.3)$ & 3.49 & $1.59-7.69$ & 3.58 & $1.58-8.12$ \\
\hline Low & {$[?] 10$} & $48(24.6)$ & $90(50.0)$ & 8.11 & $3.69-17.29$ & 8.79 & $4.01-18.97$ \\
\hline
\end{tabular}




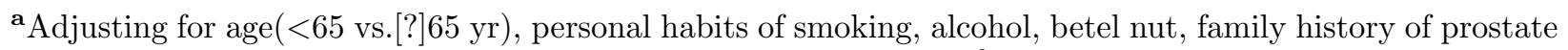
cancer, and prostatespecific antigen level (<10 vs. [?]10 ng/mL). ${ }^{\mathbf{b}}$ Medians of $42.83 \mathrm{ng} / \mathrm{mg}$ creatinine for melatonin, $23.92 \mathrm{ng} / \mathrm{mg}$. creatinine for cortisol, and 1.81 for $\mathrm{MT} / \mathrm{C}$ ratio. ${ }^{\mathbf{c}}$ Melatonin/Cortisol; ${ }^{\text {d Prostate- }}$ specific antigen.

Table 3. Association between urinary biomarkers of circadian hormone dichotomized by medians and clinical staging of prostate cancer

\begin{tabular}{|c|c|c|c|c|c|c|c|c|c|c|}
\hline & & \multirow[b]{2}{*}{$\begin{array}{l}\text { Control } \\
n=240\end{array}$} & \multicolumn{8}{|c|}{ Localized $^{\text {aLocalized }}{ }^{\text {aAdvancedAdvancedAdvanced }}{ }^{\mathrm{a}}$} \\
\hline & & & $\begin{array}{l}\text { Localized }^{a} \\
n=76\end{array}$ & $\begin{array}{l}{ }^{a} A d v a n c e d \\
n=104\end{array}$ & $\begin{array}{l}\text { dass. } \\
\text { control }\end{array}$ & $\begin{array}{l}\text { vs. } \\
\text { control }\end{array}$ & $\begin{array}{l}\text { vs. } \\
\text { control }\end{array}$ & $\begin{array}{l}\text { vs. } \\
\text { control }\end{array}$ & $\begin{array}{l}\text { vs. } \\
\text { control }\end{array}$ & $\begin{array}{l}\text { Advance } \\
\text { localized }\end{array}$ \\
\hline & & $\begin{array}{l}n \\
(\%)\end{array}$ & $\begin{array}{l}n \\
(\%)\end{array}$ & $\begin{array}{l}n \\
(\%)\end{array}$ & $\mathrm{aOR}^{\mathrm{b}}$ & $\begin{array}{l}95 \% \\
\text { CI }\end{array}$ & $\mathrm{aOR}^{\mathrm{b}}$ & $\begin{array}{l}95 \% \\
\text { CI }\end{array}$ & $\begin{array}{l}95 \% \\
\text { CI }\end{array}$ & $\mathrm{aOR}^{\mathbf{b}}$ \\
\hline Melatonir & nMelatonir & nMelatoni & nMelatonin & Melatonin & nMelatonir & Melatoni & nMelatoni & nMelatonin & Melatoni & nMelatoni \\
\hline Low & & $\begin{array}{l}108 \\
(45.0)\end{array}$ & $\begin{array}{l}40 \\
(52.9)\end{array}$ & $\begin{array}{l}69 \\
(66.7)\end{array}$ & 1.0 & $(\operatorname{Ref})$ & 1.0 & 1.0 & $(\operatorname{Ref})$ & 1.0 \\
\hline High & & $\begin{array}{l}132 \\
(55.0)\end{array}$ & $\begin{array}{l}36 \\
(47.1)\end{array}$ & $\begin{array}{l}35 \\
(33.3)\end{array}$ & 0.72 & $\begin{array}{l}0.38- \\
1.36\end{array}$ & 0.49 & 0.49 & $\begin{array}{l}0.26- \\
0.89\end{array}$ & 0.61 \\
\hline Cortisol $^{c}$ & Cortisol $^{\mathrm{c}}$ & Cortisol $^{c}$ & Cortisol $^{\mathrm{c}}$ & Cortisol $^{c}$ & Cortisol $^{\mathrm{c}}$ & Cortisol $^{\mathrm{c}}$ & Cortisol $^{\mathrm{c}}$ & Cortisol $^{\mathrm{c}}$ & Cortisol $^{\mathrm{c}}$ & Cortisol $^{\mathrm{c}}$ \\
\hline Low & & $\begin{array}{l}129 \\
(53.7)\end{array}$ & $\begin{array}{l}36 \\
(47.1)\end{array}$ & $\begin{array}{l}39 \\
(37.7)\end{array}$ & 1.0 & $(\operatorname{Ref})$ & 1.0 & 1.0 & $(\operatorname{Ref})$ & 1.0 \\
\hline High & & $\begin{array}{l}111 \\
(46.3)\end{array}$ & $\begin{array}{l}40 \\
(52.9)\end{array}$ & $\begin{array}{l}65 \\
(62.3)\end{array}$ & 1.28 & $\begin{array}{l}0.68- \\
2.41\end{array}$ & 1.96 & 1.96 & $\begin{array}{l}1.07- \\
3.57\end{array}$ & 1.87 \\
\hline$* \mathrm{MT} / \mathrm{C}^{\mathrm{c}}$ & $* \mathrm{MT} / \mathrm{C}^{\mathrm{c}}$ & ${ }^{*} \mathrm{MT} / \mathrm{C}^{\mathrm{c}}$ & ${ }^{*} \mathrm{MT} / \mathrm{C}^{\mathrm{c}}$ & $* \mathbf{M T} / \mathrm{C}^{\mathrm{c}}$ & ${ }^{*} \mathrm{MT} / \mathrm{C}^{\mathrm{c}}$ & ${ }^{*} \mathrm{MT} / \mathrm{C}^{\mathrm{c}}$ & ${ }^{*} \mathrm{MT} / \mathrm{C}^{\mathrm{c}}$ & $* \mathrm{MT} / \mathrm{C}^{\mathrm{c}}$ & ${ }^{*} \mathrm{MT} / \mathrm{C}^{\mathrm{c}}$ & ${ }^{*} \mathrm{MT} / \mathrm{C}^{\mathrm{c}}$ \\
\hline Low & & $\begin{array}{l}105 \\
(43.8)\end{array}$ & $\begin{array}{l}40 \\
(52.9)\end{array}$ & $\begin{array}{l}72 \\
(69.6)\end{array}$ & 1.0 & (Ref) & 1.0 & 1.0 & (Ref) & 1.0 \\
\hline High & & $\begin{array}{l}135 \\
(56.2)\end{array}$ & $\begin{array}{l}36 \\
(47.1)\end{array}$ & $\begin{array}{l}32 \\
(30.4)\end{array}$ & 0.63 & $\begin{array}{l}0.33^{-} \\
1.20\end{array}$ & 0.33 & 0.33 & $\begin{array}{l}0.17- \\
0.62\end{array}$ & 0.44 \\
\hline Preoperat & tRhœopera & tRœеорега & tRhæoperatl & tRhæoperat & tRиœopera & tRœœорега & tRиœорега & tRиœорегаt & tRиœopera & tRuюеope \\
\hline PSA & PSA & PSA & PSA & PSA & PSA & PSA & PSA & PSA & PSA & PSA \\
\hline $\begin{array}{l}<10 \\
\mathrm{ng} / \mathrm{mL}\end{array}$ & $\begin{array}{l}<10 \\
\mathrm{ng} / \mathrm{mL}\end{array}$ & $\begin{array}{l}120 \\
(52.4)\end{array}$ & $\begin{array}{l}28 \\
(36.8)\end{array}$ & $\begin{array}{l}12 \\
(11.5)\end{array}$ & 1.0 & (Ref) & 1.0 & 1.0 & (Ref) & 1.0 \\
\hline $\begin{array}{l}{[?] 10} \\
\mathrm{ng} / \mathrm{mL} \\
\mathbf{M T} / \mathbf{C}^{\mathbf{c}}\end{array}$ & $\begin{array}{l}{[?] 10} \\
\text { ng/mL } \\
\text { PSA** }\end{array}$ & $\begin{array}{l}109 \\
(47.6)\end{array}$ & $\begin{array}{l}48 \\
(63.2)\end{array}$ & $\begin{array}{l}92 \\
(88.5)\end{array}$ & 2.13 & $\begin{array}{l}1.10- \\
4.15\end{array}$ & 8.17 & 8.17 & $\begin{array}{l}3.77- \\
17.72\end{array}$ & 3.88 \\
\hline High & $<10$ & $\begin{array}{l}63 \\
(26.3)\end{array}$ & $\begin{array}{l}12 \\
(16.0)\end{array}$ & $\begin{array}{l}3 \\
(2.9)\end{array}$ & 1.0 & (Ref) & 1.0 & 1.0 & (Ref) & 1.0 \\
\hline Low & $<10$ & $\begin{array}{l}57 \\
(23.7)\end{array}$ & $\begin{array}{l}15 \\
(20.0)\end{array}$ & $\begin{array}{l}9 \\
(8.7)\end{array}$ & 1.44 & $\begin{array}{l}0.52- \\
3.97\end{array}$ & 3.71 & 3.71 & $\begin{array}{l}0.71- \\
19.44\end{array}$ & 2.57 \\
\hline High & [?] 10 & $\begin{array}{l}61 \\
(25.4)\end{array}$ & $\begin{array}{l}23 \\
(30.0)\end{array}$ & $\begin{array}{l}29 \\
(27.8)\end{array}$ & 2.16 & $\begin{array}{l}0.85- \\
5.46\end{array}$ & 9.36 & 9.36 & $\begin{array}{l}2.04- \\
42.91\end{array}$ & 4.34 \\
\hline Low & [?] 10 & $\begin{array}{l}48 \\
(24.6)\end{array}$ & $\begin{array}{l}26 \\
(34.0)\end{array}$ & $\begin{array}{l}63 \\
(60.6)\end{array}$ & 3.41 & $\begin{array}{l}1.34- \\
8.69\end{array}$ & 32.06 & 32.06 & $\begin{array}{l}7.17- \\
143.29\end{array}$ & 9.41 \\
\hline $\begin{array}{l}\mathrm{P} \text { for } \\
\text { multi- } \\
\text { plicative } \\
\text { interaction }\end{array}$ & & & & & 0.888 & 0.888 & 0.930 & 0.930 & 0.930 & 0.871 \\
\hline
\end{tabular}

a Localized PCa defined as stage $\mathrm{T} 1$ or T2; Advanced PCa defined as stage T3 or T4 and or distant metastases; ${ }^{\mathbf{b}}$ Adjusting for the same variables in Table 2; ${ }^{\mathbf{c}}$ Medians of $42.83 \mathrm{ng} / \mathrm{mg}$ creatinine for melatonin, $23.92 \mathrm{ng} / \mathrm{mg}$ creatinine for cortisol, and 1.81 for MT/C ratio. * c Melatonin/Cortisol ratio; **Prostate- 
specific antigen $(\mathrm{ng} / \mathrm{dL})$.

\section{Hosted file}

Table 1.pdf available at https://authorea.com/users/391928/articles/505932-urinary-melatoninsulfate-cortisol-ratio-and-the-risk-of-prostate-cancer-a-case-control-study

\section{Hosted file}

Table 2.pdf available at https://authorea.com/users/391928/articles/505932-urinary-melatoninsulfate-cortisol-ratio-and-the-risk-of-prostate-cancer-a-case-control-study

\section{Hosted file}

Table 3.pdf available at https://authorea.com/users/391928/articles/505932-urinary-melatoninsulfate-cortisol-ratio-and-the-risk-of-prostate-cancer-a-case-control-study 